EPJ Web of Conferences 12, 01005 (2011)

DOI: $10.1051 /$ epjconf/20111201005

(C) Owned by the authors, published by EDP Sciences, 2011

\title{
Aging management program of the reactor building concrete at Point Lepreau Generating Station
}

\author{
C.-M. Aldea ${ }^{1, a}$, B. Shenton ${ }^{1}$, M.M. DeMerchant ${ }^{2}$ and T. Gendron ${ }^{3}$ \\ ${ }^{1}$ AMEC Earth \& Environmental, Hamilton, Ontario, Canada \\ ${ }^{2}$ New Brunswick Power Nuclear, Point Lepreau, New Brunswick, Canada \\ ${ }^{3}$ Atomic Energy of Canada Limited, Chalk River, Ontario, Canada
}

\begin{abstract}
In order for New Brunswick Power Nuclear (NBPN) to control the risks of degradation of the concrete reactor building at the Point Lepreau Generating Station (PLGS) the development of an aging management plan (AMP) was initiated. The intention of this plan was to determine the requirements for specific structural components of concrete of the reactor building that require regular inspection and maintenance to ensure the safe and reliable operation of the plant. The document is currently in draft form and presents an integrated methodology for the application of an AMP for the concrete of the reactor building. The current AMP addresses the reactor building structure and various components, such as joint sealant and liners that are integral to the structure. It does not include internal components housed within the structure. This paper provides background information regarding the document developed and the strategy developed to manage potential degradation of the concrete of the reactor building, as well as specific programs and preventive and corrective maintenance activities initiated.
\end{abstract}

\section{INTRODUCTION}

The design life of existing nuclear power plants was often specified to be 30 to 40 years. However, utilities are realizing that it would make economic sense to extend the plant operating life to 60 years, or beyond.

The containment system in a Nuclear Power Plant (NPP) provides a final physical barrier against release of radioactive material to the outside environment. Even though there are different designs or physical configurations to meet this fundamental safety function in various reactor types, a common feature is the use of a leak tight concrete structure as part of the containment system commonly referred to as the Concrete Containment Building (CCB), or Reactor Building (RB). CSA N287.1 [1] provides details about the general requirements for concrete containment structures, which include containment system performance requirements and design requirements.

Concrete as a construction material can be very durable under a variety of environmental conditions and its performance as part of the containment function has been good. However, experience has shown that aging related distress of concrete structures can be caused by a variety of factors, some of which can be due to faulty design, use of unsuitable or poor quality materials, improper construction, exposure to aggressive environments, excessive application of loads and lack of proper maintenance. NPP operating life extension requires that the stations demonstrate that they can continue to operate the RB in a safe manner by maintaining the functional requirements, such as leak tightness and structural integrity, during the extended operating period.

ae-mail: corina.aldea@amec.com

This is an Open Access article distributed under the terms of the Creative Commons Attribution-Noncommercial License 3.0, which permits unrestricted use, distribution, and reproduction in any noncommercial medium, provided the original work is properly cited. 
A review of the international practices has shown that many utilities worldwide have been responding to the potential for age-related degradation of RBs. Therefore, they have implemented aging management programs in various forms. The Aging Management Plan (AMP) for concrete components of nuclear power plants is also being practiced in some form at each CANDU station to meet the operating license requirements [2].

PLGS has one nuclear reactor, a CANDU-6 unit, with net capacity of $635 \mathrm{MW}$. It was the first CANDU-6 to be licensed for operation, the first to achieve criticality and the first to begin commercial operation. Construction of the RB began in 1975 and was completed in 1981; commercial operation started in 1983. The plant is currently in a shutdown state and being refitted to extend the service life of the plant for an additional 25 years.

The RB containment structure comprises the exterior shell of the RB housing the nuclear reactor and the primary heat transport system. The CCB is prestressed and consists of a cylindrical perimeter wall, an upper hemispherical dome, a ring beam and a base slab. The internal structure is founded on a common base with the containment structure, but is otherwise not connected to the RB. Although the $\mathrm{RB}$ is designed as an independent structure, it functionally interfaces with the service building and the turbine building. The Canadian Standard CSA N287.7 has code provisions for in-service examination and testing for leak tightness of CCB, pre-stressing system integrity evaluation, and examination of liners and joint sealants [3].

In 2009 PLGS undertook the development of an AMP to specifically address the inspection, care and maintenance of the RB, similar to the AMPs developed for the other critical components of the plant. This development was conducted in two sequential steps:

- Preparation of a technical basis document presenting a detailed integrated methodology for the application of an AMP for the concrete of the RB at PLGS [4], and

- Development of an AMP summarizing RB degradation and its management, including specific elements and activities, as well as short term and long term plans for the RB at PLGS [5].

\section{METHODOLOGY}

The methodology set forth in the AMP for the concrete of the RB involves activities and tasks for: periodic inspections to identify and assess defects, monitoring and mitigation of defects by existing, modified, or new maintenance activities, techniques for repair of defects, record keeping, continued integrity assessment and trending assessment for continued service life determination. The AMP includes the following sequential steps:

1) Program organization and information gathering. This is related to the proposed definition of the AMP team, their responsibilities and specific qualifications, as detailed in CSA N287.1 [1] and ACI 349-3R [6]; gathering and reviewing plant documentation; defining relevant areas for data collection, such as accessible and inaccessible areas and; conducting a general visual examination of the relevant areas identified.

2) Defect evaluation, including condition survey and evaluation of condition survey results. Defects identified in step 1 must be evaluated using acceptance criteria defined in [6]. Those defects that do not meet the stated acceptance criteria must be evaluated to determine corrective actions, re-inspections and alternative or supplemental examinations. If the condition of the defects or deterioration suggests that further degradation data is required, materials testing and structural analysis are required.

3) Remedial actions should be taken to repair, or replace the damaged components to mitigate the cause of deterioration. ACI 546R [7] and ACI 546.3R [8], provide detailed information and guidance on the selection and application of materials and methods for the repair, protection and strengthening structures in general. CSA N287.2 [9] and COG 04-4055 [10] provide information regarding the material requirements for concrete containment structures for CANDU nuclear power plants, and patching and overlay materials for repairing concrete structures materials 
AMP 2010

performance characteristics and repair specifications. The defects that need to be repaired are prioritized based on the safety significance and state of degradation of the concrete component, and the inspection results are reported and stored.

4) Continued service determination, including continued integrity assessment and trending refers to the evaluation of the effectiveness of the AMP to ensure safe and reliable operation of the plant. The factors controlling the service life of concrete and the methodologies to predicting the service life of concrete presented in ACI 365.1R [11] and [2] can assist the integrity assessment and trending of the concrete of the RB.

\section{PROGRAM ELEMENTS}

The AMP developed for the RB at PLGS follows the standard set out for all AMP in place at the site. It is practical and includes trends and facts which are most relevant to the RB maintenance [5]. It includes measures to detect, test, mitigate, record and report the condition including significant degradation and aging effects. The plan covers the management of materials and components which are accessible and inaccessible to data collection. However, this paper focuses on concrete components of the RB structure, as defined below, and to a limited extent to other components whose distress can initiate concrete degradation.

- Accessible components are the following: prestressed concrete containment systems and boundaries, including RB dome, ring beam, perimeter wall and buttresses the dousing tank, nonmetallic liners, organic components and sealants.

- Inaccessible components are the following: prestressed and reinforcing steel.

The key elements of the AMP are the following:

\subsection{Design basis review}

A design basis review includes a list of design and performance requirements based on nuclear safety considerations, license requirements, review of mandatory maintenance requirements, review of reporting, acceptance and disposition criteria, conducting leakage rate testing, conducting in-service examination and monitoring and external agency action items and commitments. The primary regulatory requirement for operation of the $\mathrm{RB}$ is compliance with pressurized leakage rate testing [3]. According to the PLGS Operating Policies and Principles the acceptance leakage rate is taken as $0.5 \%$ of the containment volume per day at $18 \mathrm{psig}(124 \mathrm{kPa})$ internal air pressure. Table 1 presents proposed specific acceptance criteria for various in-service examination and monitoring results developed based on [6].

\subsection{Relevant internal and external operating experience}

A review of relevant internal and external operating experience was conducted, including results of visual inspections conducted on the RB in 2000 and 2009, historic leak rate test (LRT) data and in-situ monitoring. The inspections performed at PLGS in 2000 and 2009 indicated that the RB is generally in good condition and there is no significant degradation observed, or anticipated degradation with unmanageable failure rate, or safety significance.

Two key design advantages have been identified compared to other RBs of similar age:

- The concrete of the RB contains fly ash (FA) in the mix design. FA is a supplementary cementitious material which is known to have the following beneficial effects, when used in concrete: reduce the risk of early age thermal stress and cracking in concrete during construction, to reduce the water and chloride-ion permeability, especially at later ages, to increase the protection of reinforcing steel from corrosion, to increase the resistance to sulphate attack and to control alkali-aggregate reaction (AAR, e.g. expansion) in concrete [12]. It is believed that the use of FA in the concrete of 
EPJ Web of Conferences

Table 1. Acceptance criteria for RB monitoring and inspection results (under review).

\begin{tabular}{|c|c|c|c|}
\hline Observation & Acceptable & $\begin{array}{l}\text { Engineering } \\
\text { assessment or more } \\
\text { inspection required }\end{array}$ & $\begin{array}{l}\text { Corrective action } \\
\text { required }\end{array}$ \\
\hline \multicolumn{4}{|c|}{ Concrete components } \\
\hline $\begin{array}{l}\text { Dome } \\
\text { thickness }\end{array}$ & $>610 \mathrm{~mm}$ & $<610 \mathrm{~mm}$ & - \\
\hline Cracks & $\begin{array}{l}\text { Hairline and no } \\
\text { evidence of } \\
\text { leaching }\end{array}$ & $\begin{array}{l}\text { Evidence of } \\
\text { leaching and } \\
>0.4 \mathrm{~mm} \text { wide }\end{array}$ & $\begin{array}{l}\text { Associated rust } \\
\text { staining, spalling } \\
\text { or scaling }\end{array}$ \\
\hline Concrete cover & $>50 \mathrm{~mm}$ & $<50 \mathrm{~mm}$ & Exposed rebar \\
\hline $\begin{array}{l}\text { Localized loss } \\
\text { of material } \\
\text { (voids, spalling) }\end{array}$ & $\begin{array}{l}<10 \mathrm{~mm} \text { deep and } \\
<10 \mathrm{~mm} \text { deep and }\end{array}$ & $\begin{array}{l}10-20 \mathrm{~mm} \text { deep and } \\
10-20 \mathrm{~mm} \text { deep and }\end{array}$ & $\begin{array}{l}>20 \mathrm{~mm} \text { deep and } \\
>20 \mathrm{~mm} \text { deep and }\end{array}$ \\
\hline $\begin{array}{l}\text { Dome topping } \\
\text { coverage }\end{array}$ & $\begin{array}{l}<20 \% \text { surface } \\
\text { area lost }\end{array}$ & $\begin{array}{l}20-50 \% \text { surface } \\
\text { area lost }\end{array}$ & $\begin{array}{l}>50 \% \text { surface } \\
\text { area lost }\end{array}$ \\
\hline $\begin{array}{l}\text { Stress/strain } \\
\text { monitoring }\end{array}$ & $\begin{array}{l}\text { Measurement return } \\
\text { within } 10 \% \text { of pre-RB } \\
\text { leaking rate test values }\end{array}$ & $\begin{array}{l}\text { Measurement vary by } \\
\text { more than } 10 \% \text { of pre-RB } \\
\text { leaking rate test values }\end{array}$ & \\
\hline $\begin{array}{l}\text { RB deflection } \\
\text { monitoring }\end{array}$ & $\begin{array}{l}\text { Within design } \\
\text { limits }\end{array}$ & $\begin{array}{l}\text { Above design } \\
\text { limits }\end{array}$ & \\
\hline $\begin{array}{l}\text { Embedded } \\
\text { debris }\end{array}$ & $\begin{array}{l}\text { No associated } \\
\text { distress to local } \\
\text { concrete }\end{array}$ & $\begin{array}{l}\text { Concrete degradation } \\
10-20 \mathrm{~mm} \text { deep and } \\
100-400 \mathrm{~mm}^{2}\end{array}$ & $\begin{array}{l}\text { Concrete degradation } \\
>20 \mathrm{~mm} \text { deep and } \\
>400 \mathrm{~mm}^{2}\end{array}$ \\
\hline \multicolumn{4}{|c|}{ Concrete reinforcement } \\
\hline $\begin{array}{l}\text { Half cell } \\
\text { potential }\end{array}$ & $>-0.2 \mathrm{~V}$ & $-0.35--0.2 \mathrm{~V}$ & $<-0.35 \mathrm{~V}$ \\
\hline \multicolumn{4}{|c|}{ Other components } \\
\hline $\begin{array}{l}\text { Sealant } \\
\text { condition }\end{array}$ & $\begin{array}{l}\text { No failure in bond } \\
\text { to adjacent concrete }\end{array}$ & $\begin{array}{l}\text { Biofouling observed } \\
\text { or detached from } \\
\text { substrate }<10 \mathrm{~cm} \\
\end{array}$ & $\begin{array}{l}\text { Detached from } \\
\text { substrate }>10 \mathrm{~cm}\end{array}$ \\
\hline $\begin{array}{l}\text { Liner } \\
\text { condition }\end{array}$ & $\begin{array}{l}\text { No visible damage } \\
\text { and adhesion test } \\
>700 \mathrm{kPa}\end{array}$ & - & $\begin{array}{l}\text { Visible damage } \\
\text { or adhesion test } \\
<700 \mathrm{kPa} \text { adhesion }\end{array}$ \\
\hline
\end{tabular}

the RB at PLGS is the principal reason for its observed superior performance compared to other RBs of similar age.

- The concrete overlay on the ring beam at PLGS provides additional protection to embedded components in the ring beam compared to plants without an overlay.

Despite these design advantages, lack of a regular inspection and maintenance has led to various degraded conditions that require immediate and ongoing attention to ensure good performance during the remaining life of the plant.

The visual inspections conducted in 2000 and 2009 for the ring beam and overlay, perimeter wall and upper dome revealed the following types of defects:

- Surface and near-surface defects, such as concrete spalling, exposed reinforcing steel and ties, cracking with leached carbonate materials in the ring beam and perimeter wall. The defects in the ring beam were more severe than those observed for the perimeter wall. 
Table 2. Historic leak rate test results.

\begin{tabular}{|l|c|c|}
\hline \multirow{2}{*}{ Year tested } & \multicolumn{2}{|c|}{ Leak rate (\% volume per day) } \\
\cline { 2 - 3 } & Reactor building & Spent fuel discharge bay \\
\hline 2004 & 0.479 & 0.015 \\
\hline 2000 & 0.380 & 0.015 \\
\hline 1997 & 0.401 & 0.036 \\
\hline 1994 & 0.470 & 0.060 \\
\hline 1990 & 0.330 & 0.050 \\
\hline 1987 & 0.580 & 0.067 \\
\hline 1982 & 0.260 & Not recorded \\
\hline 1981 & 0.340 & Not recorded \\
\hline
\end{tabular}

- In 2008 a 3 meter-long crack was observed in the ring beam overlay associated with delamination of concrete in the area. This crack was likely due to progressive freeze-thaw damage from water ingress through failed joint sealant. However, no degradation of the underlying structural concrete of the ring beam was identified at the time.

- Flaking and delamination of the concrete on the soffit and face of the ring beam caused by debris embedded in the concrete during construction, including wood chips, plastic, polystyrene foam, nails, loose rebar tie wire.

- Voids in non-structural concrete filling tensioning cable box-out on the ring beam, which were caused by inadequate consolidation of concrete into the box out recesses during concrete placement.

- Non-uniform concrete cover on the upper dome due to inadequate cover at the time of construction.

- Loss of protective topping material on the upper face of the dome.

- Widespread degradation and failure of joint sealants.

Among the defects identified during the visual inspections conducted in 2000 and 2009 the following two types of construction defects have potential to promote degradation:

1. Embedded debris in the concrete, as a result of materials left in the formwork prior to concrete placement, and

2. Cable box outs behind the ring beam overlay.

CSA N287.7-08 [3] has code provisions for in-service examination and testing for leak tightness of the RB, including the frequency of the RB LRT. Historic LRT results at PLGS presented in Table 2 show that in 1987 the RB leak rate reached a peak which exceeded the acceptance criterion. To mitigate this situation, a polyurethane liner (Normac $($ ) was applied over the original epoxy liner on the inside of the RB. The new liner was applied in stages over a period of several years and has resulted in significant decreases in leak rate test results beginning in 1990. Although subsequent test results fluctuated, they remained within specified limits, as shown in Table 2. Since the RB is a post-tensioned concrete structure, the LRT should not cause any external cracking. However, cracks have been observed in the perimeter wall and ring beam overlay during the 2000 and 2009 visual inspections. To date it has not been determined whether cracking is initiated or propagated due to stresses imposed during the LRT, or is the result of normal concrete strain and aging, or an artifact of construction sequencing. Additionally, due to the presence of the liner the internal surface of the RB structure is inaccessible and cannot be inspected. 


\section{EPJ Web of Conferences}

\subsection{Dominant failure modes and degradation mechanisms}

Degradation mechanisms for concrete of the RB apply to effects produced by internal material reaction, the external environment and normal plant operations. Mechanisms that have been cited in [6] as having the greatest threat to long-term performance to reinforced concrete of the RB, and which have been addressed in the draft AMP are degradation mechanisms for concrete, steel reinforcement and prestressing steel, liners and sealants. For each of the degradation mechanisms key factors, possible locations and management concerns were outlined. The dominant failure modes and degradation mechanisms of the concrete of the RB at PLGS include:

- Physical/mechanical degradations, such as: material loss from contact with moving solids and fluids, fatigue, freeze-thaw damage, volume changes, overloads from off-normal conditions or pressure tests, degradation from embedded debris, and

- Environmental degradation, such as: chemical attack, leaching, cement-aggregate reactions, degradation from irradiation and thermal exposure and biofouling.

Degradation or failure of the steel reinforcement and prestressing steel, liner and/or sealants can be a precursor to other potential degradation mechanisms in concrete.

\subsection{Testing and inspection criteria and options}

RB components are potentially susceptible to a wide variety of degradation mechanisms, many of which are interdependent. Accordingly, the AMP of the RB at PLGS developed the aging management strategy for future operation of the RB consists of inspection and repair. The purpose of inspection, monitoring and testing is to monitor component condition and early identification of unacceptable degradation. Once identified, repair and other preventative measures can be implemented to mitigate and prevent further damage. A detailed list of elements and activities that are used to manage degradation of different reactor building components, including categories, such as degradation mechanism, issues of concern and primary strategy to manage degradation was developed, but is not presented here. The potential degradation mechanisms were classified in active degradation under normal conditions and likely degradation under off-normal conditions.

\subsection{Recommended risk-reduction plans}

The strategy for mitigating issues in place consists of defining short-term plans for RB component conditions and repairing the existing damage, as well as developing long-term plans to maintain the repaired condition. Tables 3 and 4 present short term inspection and monitoring and maintenance/repair plans for the RB at PLGS.

\section{PROGRAM IMPLEMENTATION}

\subsection{Detailed condition assessment}

Following the development of the draft AMP of the RB at PLGS, detailed condition assessments of the dome and the ring beam of the RB were conducted during the spring of 2010. These condition assessments were part of the 2010 program to identify deficiencies, recommend appropriate repair methodologies and initiate repairs of the most significant issues. They consisted of observations and testing conducted during the field investigations, identifying areas of concern and providing recommendations for repair of any noted deficiencies.

The field investigations included detailed visual inspections, hammer sounding to identify the presence and extent of delamination, half-cell corrosion potential survey to determine the probability of rebar corrosion and chloride ion sampling to determine the presence of salts that could promote rebar 
AMP 2010

Table 3. Short term inspection and monitoring plan, 2010.

\begin{tabular}{|c|c|c|}
\hline Activity & Objective & Location \\
\hline \multirow[t]{4}{*}{ Visual inspection } & Topping survey & Upper dome \\
\hline & \multirow[t]{3}{*}{ Crack mapping and sounding } & Upper dome \\
\hline & & Ring beam and overlay \\
\hline & & Perimeter wall and buttresses \\
\hline Impact echo & Dome thickness & Upper dome \\
\hline \multirow[t]{4}{*}{ Ground penetrating radar (GPR) } & \multirow[t]{4}{*}{ Cover survey } & Upper dome \\
\hline & & Ring beam and overlay \\
\hline & & $\begin{array}{l}\text { Upper } 300 \mathrm{~cm} \text { of perimeter } \\
\text { wall and buttresses }\end{array}$ \\
\hline & & $\begin{array}{l}\text { Lower area of perimeter wall } \\
\text { and buttresses }\end{array}$ \\
\hline Half-cell measurements & Rebar corrosion survey & Upper dome and ring beam \\
\hline $\begin{array}{l}\text { Stress-strain displacement } \\
\text { monitoring }\end{array}$ & Response to leak rate test & RB dome and perimeter wall \\
\hline
\end{tabular}

Table 4. Short term maintenance/repair plan, 2010.

\begin{tabular}{|c|c|c|}
\hline Activity & Method & Location \\
\hline \multirow{4}{*}{$\begin{array}{l}\text { Joint and penetration } \\
\text { sealant repair }\end{array}$} & \multirow{4}{*}{$\begin{array}{l}\text { Remove and replace } \\
\text { damaged material }\end{array}$} & Ring beam \\
\hline & & $\begin{array}{l}\text { Shield wall perimeter } \\
\text { wall joint }\end{array}$ \\
\hline & & Penetrations \\
\hline & & $\begin{array}{l}\text { Cable recess box-out to } \\
\text { buttress vertical joint }\end{array}$ \\
\hline \multirow[t]{3}{*}{ Concrete repair } & $\begin{array}{l}\text { Epoxy or cement grout } \\
\text { injection and/or patching }\end{array}$ & $\begin{array}{l}\text { All visually inspected } \\
\text { surface area }\end{array}$ \\
\hline & $\begin{array}{l}\text { Remove and replace } \\
\text { damaged material }\end{array}$ & $\begin{array}{l}\text { Delamination and associated } \\
\text { cracking of ring beam overlay }\end{array}$ \\
\hline & $\begin{array}{l}\text { Remove damaged material, } \\
\text { debris and repair }\end{array}$ & $\begin{array}{l}\text { Poputs and spalled mortar } \\
\text { patches in top } 300 \mathrm{~cm} \text { of } \\
\text { perimeter wall }\end{array}$ \\
\hline \multirow[t]{2}{*}{ Normal liner repair } & $\begin{array}{l}\text { Apply liner in } \\
\text { uncoated areas }\end{array}$ & $\begin{array}{l}\text { Center of the upper } \\
\text { dome and other poorly } \\
\text { accessible areas }\end{array}$ \\
\hline & $\begin{array}{l}\text { Repair locations } \\
\text { of delamination }\end{array}$ & $\begin{array}{l}\text { All visually inspected } \\
\text { surface area in } \mathrm{RB} \\
\text { and dousing tank }\end{array}$ \\
\hline
\end{tabular}

corrosion. Additionally, ground penetrating radar (GPR) surveys were conducted to identify voids in the non-structural ring beam overlay and cable box-outs and to determine the thickness of the concrete cover for the dome.

The findings of the field investigations conducted in 2010 are generally in agreement with the visual inspections conducted in 2000 and 2009. The condition assessment in 2010 indicated that the overall condition of the concrete of the dome and ring beam is good. However, degradation requiring remedial steps to ensure continued good performance was identified. There are some similarities between the main types of distress identified for the dome and ring beam; however, distress is more severe on the 
ring beam than the dome. The significant finds of the condition assessments are as follows:

- Failure of the joint sealant, which is either debonded from the concrete, lose, or missing at nearly all of the joints of the ring beam, or weathered, dry, cracked and bebonded from the concrete in several areas at the joint between the dome and upper ring beam. As pointed out in the strategy of the draft AMP degradation failure of the joint sealant is a precursor to other potential degradation mechanisms. Failure of the sealant at the joint between the top of concrete overlay and the upper ring beam has allowed water to penetrate into the joints and caused leaching of some materials along the joints, or allowed the water to be trapped and be channeled behind the overlay. Figures 1 and 2 show failure of the joint sealant between the top of the concrete overlay and the upper ring beam, which has permitted the accumulation of sediment and facilitated the growth of organic material. GPR survey and drilling suspect areas in the concrete overlay revealed small areas soft, moist, or water saturated concrete, in some of the cable box-outs which is most likely the result of poor consolidation during construction and failure of the sealant at the top of the overlay.

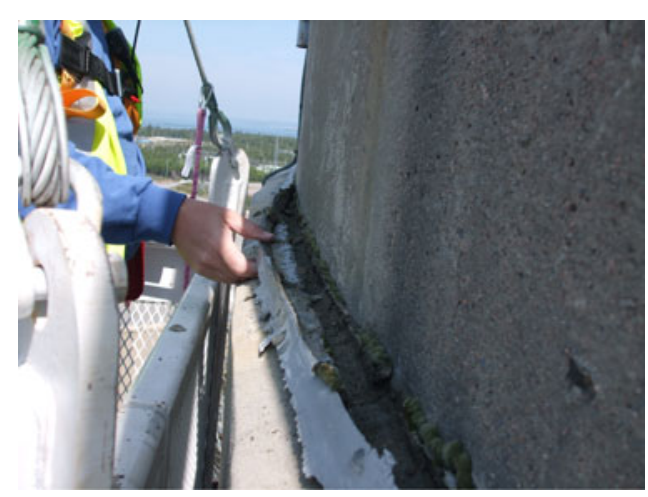

Figure 1. Failed sealant at joint between the top of concrete overlay and upper RB ring beam.

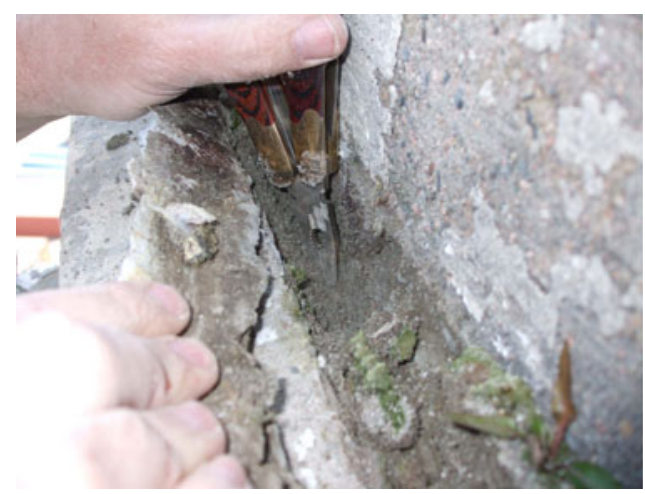

Figure 2. Configuration of joint top concrete overlay showing sealant failure.

- Delamination of the non-structural concrete overlay of the ring beam. A significant amount of debonding was revealed by hammer sounding on the concrete overlay. The delaminations typically extend 300-400 $\mathrm{mm}$ up from the bottom of the overlay and 150-200 $\mathrm{mm}$ down from the top edge. The delaminated areas were delineated and identified on the structure, as shown in Figure 3, and are an artifact of the original construction detail.

- Exposed steel reinforcement bars were observed both on the surface of the ring beam and at several locations on the dome. The exposed rebars were typically corroded and they caused in many cases localized delamination of concrete adjacent to exposed bars.

- Concrete cover over the reinforcing steel of the dome below the normally specified thickness $50 \mathrm{~mm}$. GPR equipment was used to continuously scan twelve concentric circles of the survey grid. Figure 4 presents a map of the minimum concrete cover of the dome, where in each element represented there is at least one rebar with the minimum cover indicated. The survey identified significant areas of thin concrete cover, with an average cover ranging between $25 \mathrm{~mm}$ and $50 \mathrm{~mm}$, including the outer 3-4 meters of the dome. The low concrete cover of the outer ring of the dome is likely caused by the difficulty of placing concrete due to the geometry of the dome. Reinforcing steel corrosion potential testing on the dome and ring beam, determined by the half-cell corrosion potential method following ASTM C876 [13] revealed a 90\% probability that corrosion is not occurring in the steel reinforcement. Of the over 1200 readings taken, none indicated potential for corrosion to be present in the embedded reinforcement. Concrete samples recovered from the dome and ring beam were tested in the laboratory for chloride ion content following ASTM 
AMP 2010

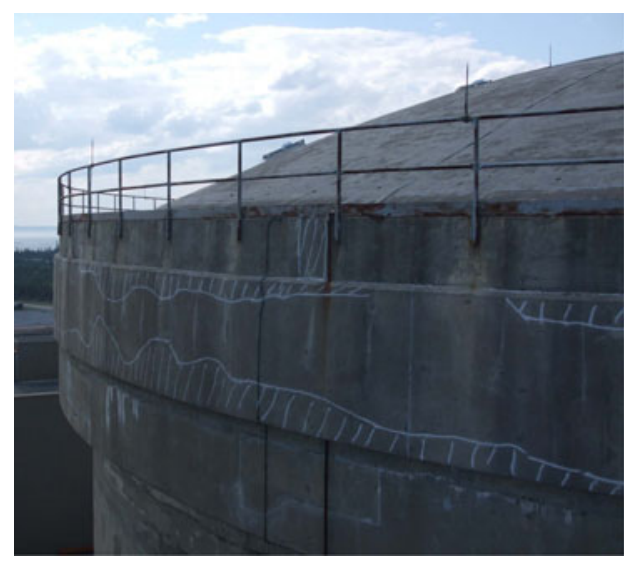

Figure 3. Delamination of non-structural concrete overlay of the ring beam.

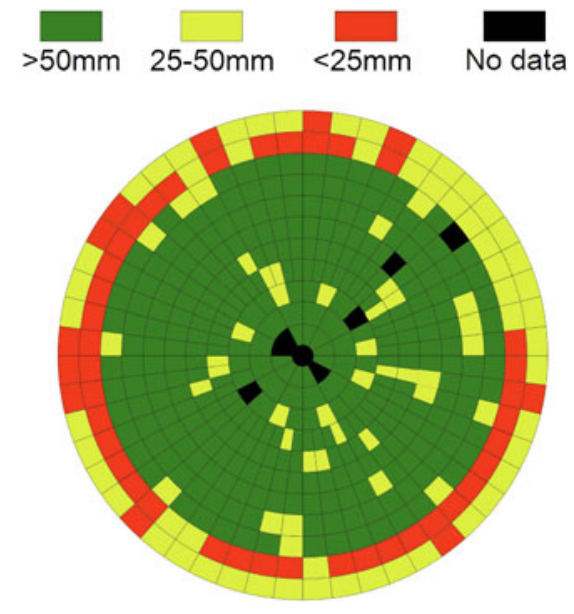

Figure 4. Map showing minimum concrete cover of the RB dome.

C1218 [14] and depth of carbonation by the phenolphthalein method. Test results indicated that the concentration of chlorides in the concrete below $10 \mathrm{~mm}$ from the surface is significantly below the normal threshold required to induce corrosion in steel reinforcement. In addition, the concrete is maintaining a high $\mathrm{pH}$ below $10 \mathrm{~mm}$, which indicates that no significant carbonation has occurred, and which in turn prevents initiation of rebar corrosion. It should be pointed out that in spite of the exposed rebar observed at locations both on the ring beam and dome, as well as the areas of thin concrete cover of the dome, the results of the tests conducted on site and in the laboratory indicated that no corrosion is occurring in the steel reinforcement.

- Embedded contamination of the concrete of the ring beam, in the form of lumber, wood chips, saw dust, nails, wire, plastic etc, has caused some localized distress to the structural concrete at various locations in the structure (Figure 5).

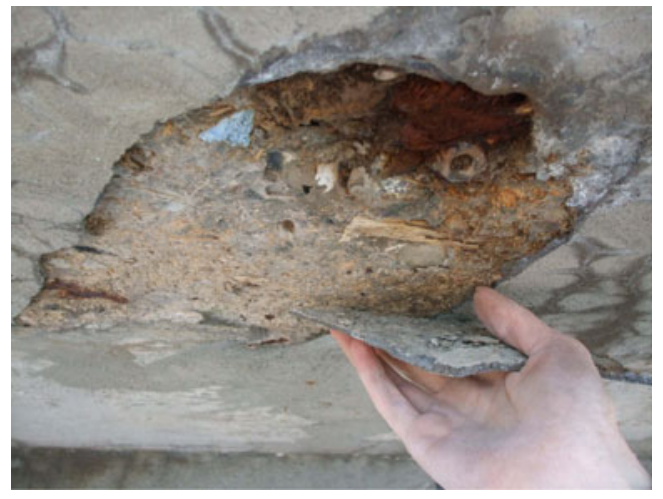

Figure 5. Embedded contamination on soffit of lower ring beam including foam insulation, wood chips, saw dust, steel nut and nails.

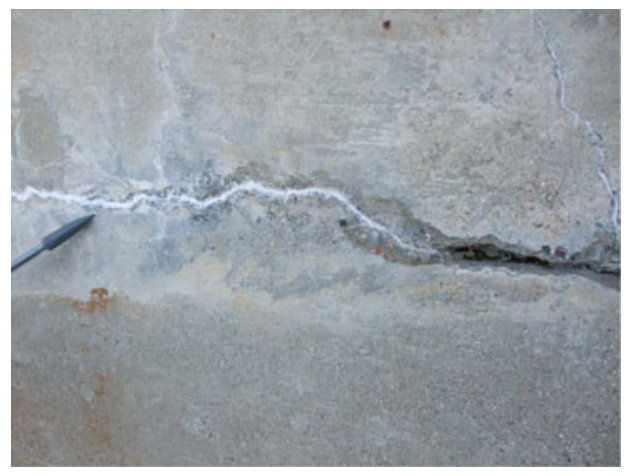

Figure 6. Crack filled with mineral deposits in the ring beam. 


\section{EPJ Web of Conferences}

- Concrete cracks filled with mineral deposits. Cracking was more severe in the ring beam, ranging from hairline cracks to $1 \mathrm{~mm}$ crack width, than in the dome, where only limited hairline cracks were observed (Figure 6).

- Concrete topping which is weathered, eroded and missing on approximately $50 \%$ of the dome.

\subsection{Repair measures}

Based on the recommendations made for repair of any deficiencies identified by the detailed condition assessment of the dome and ring beam conducted in 2010, repair materials have been selected following CSA N287.2 [9] and COG-04-4055 [10]. The types of distress identified have been prioritized and a repair program has been developed and initiated. The repair, or repair related, activities completed, or in progress, are the following:

- Development of concrete repair details for areas requiring repair, as found during 2010 inspections. Repair details include the replacement of the joint sealants, concrete repair, or replacement at post tension box-outs, epoxy injection and possible pinning of concrete overlay, as well as removal and replacement of concrete overlay at identified locations.

- Erection of temporary work platform around the circumference of the RB at the ring beam elevation to facilitate concrete repair work.

- Filling voids discovered in the tension box-outs behind concrete overlay. The concrete overlay was removed in the area to facilitate concrete placement and the two voids identified were filled.

- Sealant replacement. COG qualified and accepted material [10] was used for sealant replacement of the horizontal joint between the concrete overlay and the ring beam, as well as of all the vertical construction joints in the ring beam concrete overlay (Figures 7 and 8).

- Post tension box-outs repairs. Concrete was replaced in all box-outs that are above the elevation of the horizontal joint of the concrete overlay and the ring beam. Figure 9 presents an intermediate repair step after removal of concrete. Figure 10 presents a feathered edge box-out repair completed.

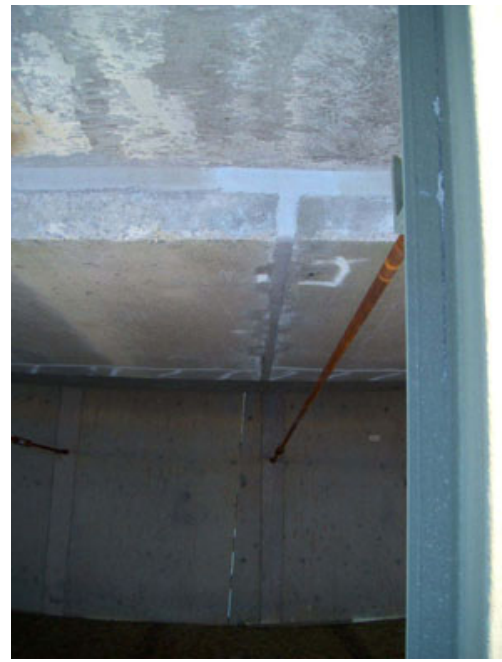

Figure 7. Repaired joint sealant (horizontal and vertical) of the concrete overlay.

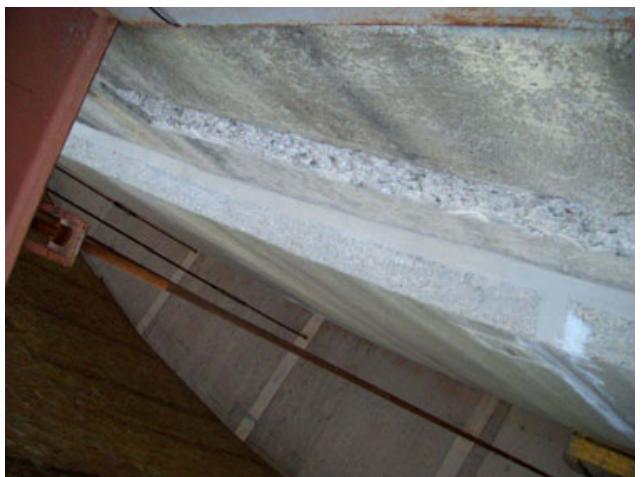

Figure 8. A shallow repair area above the joint between the concrete overlay and the ring beam and repair sealant. 
AMP 2010

- Trial of epoxy injection. COG qualified and accepted material [10] was used for one trial section of epoxy injection to the delaminated interface of the ring beam and concrete overlay.

- Ongoing repair RB ring beam and dome activities. Ring beam repairs to be completed include the repair of the construction joint between the upper and lower ring beam, post tension box-outs repairs in all remaining box-outs requiring repairs, epoxy injection to the delaminated interface of the ring beam and concrete, pouring replacement overlay concrete at areas where concrete overlay was removed, as well as other spot repairs, as identified. Dome repairs to be completed include the repair and replacement of the construction joint between the upper ring beam and dome, exposed rebar repairs and re-coating of the dome with the same weatherproof topping.

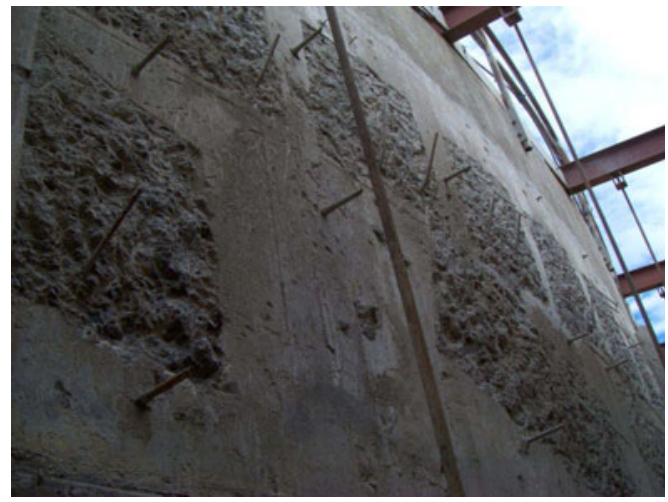

Figure 9. Face of the ring beam with box-outs after removal of a section of the concrete overlay.

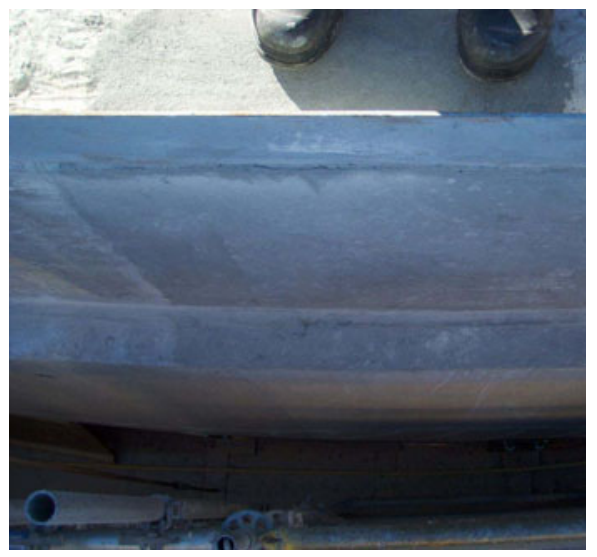

Figure 10. Feathered edge box out after repair.

\section{SUMMARY AND CONCLUSIONS}

- A draft AMP was developed to monitor the health of the concrete of the RB at PLGS.

- The program elements include: design basis review, review of relevant internal and external operating experience, review of potential dominant failure modes and degradation mechanisms, development of a strategy for the management plan, development of recommended short term and long term risk-reduction plans and development of a strategy for mitigating aging issues.

- The draft AMP is currently being implemented. Based on the short term inspection, monitoring and maintenance/repair plan developed, condition assessments of the dome and the ring beam were conducted in 2010 to identify deficiencies, recommend appropriate repair methodologies and initiate repairs needing immediate attention.

- The findings of the condition assessment for the ring beam and dome in 2010 are in agreement with those of the visual inspections conducted in 2000 and 2009.

- The main types of distress identified in 2010 include the following: failure of the joint sealant, delamination of non-structural concrete of the ring beam overlay, exposed rebar, concrete cover over the rebar of the dome which is below specified thickness, embedded contamination of the concrete in the ring beam, loss and erosion of the topping on the dome and concrete cracks filled with mineral deposits. 
- Overall the structural elements investigated are in satisfactory conditions; however, some deficiencies were identified that require remedial action to ensure continued good performance of the RB. These deficiencies are more prevalent on the ring beam than the dome.

- Repair methodologies of the deficiencies identified were recommended to ensure maintaining the ability of the RB to perform its design function and the safe and reliable operation of the plant.

- A repair program has been developed and initiated.

\section{References}

[1] CSA N287.1-93 (R2009) General Requirements for Concrete Containment Structures for CANDU Nuclear Power Plants.

[2] Philipose K., Aging management program for CANDU concrete containment structures, COG08-4042, 60p., 2009.

[3] CSA N287.7-08 In-service Examination and Testing Requirements for Concrete Containment Structures for CANDU Nuclear Power Plants.

[4] Aldea C.-M., Concrete containment structure technical basis document, PLGS, 83p., 2009.

[5] Demerchant M. and Gendron T., Reactor building management plan EPP-21000-RB01, PLGS, 52p., 2010.

[6] ACI 349.3R-02 Evaluation of Existing Nuclear Safety-Related Concrete Structures.

[7] ACI 546R-04 Concrete Repair Guide.

[8] ACI 546.3R-06 Guide to the Selection of Materials for the Repair of Concrete.

[9] N287.2-08 Material requirements for concrete containment structures for CANDU nuclear power plants.

[10] COG 04-4055 Evaluation of patching and overlay materials for repairing concrete structures long term performance monitoring for CANDU generating stations - Materials performance characteristics and repair specification, 2006.

[11] ACI 365.1R-00 Service Life Prediction.

[12] ACI 232.2R - 03 Used of fly ash in concrete.

[13] ASTM C876-09 Standard Test Method for Half-Cell Potentials of Uncoated Reinforcing Steel in Concrete.

[14] ASTM C1218 / C1218M - 99(2008) Standard Test Method for Water-Soluble Chloride in Mortar and Concrete. 